\title{
Early stages of anchovy: abundance, variability and larval condition at the fixed coastal station EPEA between 2000-2017
}

\author{
Ezequiel Leonarduzzi ${ }^{1}{ }^{*}$, Marina Do Souto $^{1,2}$ and Marina V. Diaz ${ }^{1,2}$ \\ ${ }^{1}$ Instituto Nacional de Investigación y Desarrollo Pesquero (INIDEP), Paseo Victoria Ocampo No 1, Escollera Norte, B7602HSA - \\ Mar del Plata, Argentina. ${ }^{2}$ Instituto de Investigaciones Marinas y Costeras (IIMyC-CONICET), Facultad de Ciencias Exactas y Naturales, \\ Universidad Nacional de Mar del Plata (UNMdP), Consejo Nacional de Investigaciones Científicas y Técnicas (CONICET), Argentina. \\ ORCID Ezequiel Leonarduzzi (D) https://orcid.org/0000-0002-6232-0478, Marina Do Souto (D) https://orcid.org/0000-0002-2259-0115, \\ Marina V. Diaz (D) https://orcid.org/0000-0002-2912-5232
}

Marine and Fishery Sciences MAFIS

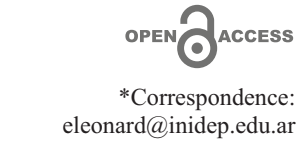

Received: 26 September 2020 Accepted: 11 March 2021

ISSN 2683-7595 (print) ISSN 2683-7951 (online)

https://ojs.inidep.edu.ar

Journal of the Instituto Nacional de Investigación y Desarrollo Pesquero (INIDEP)

This work is licensed under a Creative Commons AttributionNonCommercial-ShareAlike 4.0 International License

\begin{abstract}
Densities of eggs and larvae of Engraulis anchoita and the nutritional condition of larvae were analyzed in the fixed sampling station (EPEA) in the period 2000-2017. These variables were analyzed seasonally and trends over time were determined. Ichthyoplankton samples were collected by oblique trawls using Bongo nets with $300 \mu \mathrm{m}$ of pore mesh and fixed with formaldehyde $5 \%$ in seawater. Six morphometric variables were measured to estimate the nutritional condition of larvae. The developmental stage of each specimen was also determined. The highest mean value of egg density was detected in the October-December period, with a secondary mode in August, followed by one in March. Larval density presented a mode in October. Autumn and spring were the most favorable seasons for larval condition while winter proved to be the least favorable one. An increase in food availability during autumn and spring due to primary and secondary production peaks could explain the high nutritional condition and growth values observed in these seasons at the EPEA. No changes in trends of variables over time were detected. The integrated study of density and nutritional condition of $E$. anchoita larvae allows the determination of favorable breeding periods for the species, while the continuation of the long term study will allow evaluating possible effects of climate change in the early life stages of this species.
\end{abstract}

Key words: Engraulis anchoita, ichthyoplankton, nutritional condition, seasonality, time series.

Etapas tempranas de la anchoíta: abundancia, variabilidad y condición larval en la estación fija EPEA entre 2000-2017

RESUMEN. Se analizaron las densidades de huevos y larvas de Engraulis anchoita y el estado nutricional de las larvas en la estación de muestreo fija (EPEA) en el período 2000-2017. Estas variables se analizaron estacionalmente y se determinaron las tendencias en el tiempo. Las muestras de ictioplancton se recolectaron mediante arrastres oblicuos utilizando redes Bongo con $300 \mu \mathrm{m}$ de poro de malla y se fijaron con formaldehído al $5 \%$ en agua de mar. Se midieron seis variables morfométricas para estimar el estado nutricional de las larvas. También se determinó la etapa de desarrollo de cada espécimen. El mayor valor medio de densidad de huevos se detectó en el período octubre-diciembre, con una moda secundaria en agosto, seguida de otra en marzo. La densidad larvaria presentó una moda en octubre. El otoño y la primavera fueron las estaciones más favorables para la condición larvaria, mientras que el invierno resultó ser la menos favorable. Un aumento en la disponibilidad de alimentos durante el otoño y la primavera debido a los picos de producción primaria y secundaria podría explicar el alto estado nutricional y los valores de crecimiento observados en estas temporadas en la EPEA. No se detectaron cambios en las tendencias de las variables a lo 
largo del tiempo. El estudio integrado de densidad y condición nutricional de larvas de E. anchoita permite determinar períodos de cría favorables para la especie, mientras que la continuación del estudio a largo plazo permitirá evaluar posibles efectos del cambio climático en las primeras etapas de vida de esta especie.

Palabras clave: Engraulis anchoita, ictioplancton, condición nutricional, estacionalidad, series de tiempo.

\section{INTRODUCTION}

Ichthyoplankton is the key component that links primary, secondary and tertiary levels of the trophic web in the sea. Fish generally spawn in relation to the primary and secondary production cycles and consequently, ichthyoplankton densities fluctuate throughout the year (Govoni 2005). Pájaro et al. (2009) estimated the adult Engraulis anchoita biomass from 1996 to 2004 in the Argentine sea based on the analysis of ichthyoplankton samples obtained in 10 surveys. These authors demonstrated the importance of ichthyoplankton analyzes in the understanding of recruitment and management research, in this case using a daily egg production method. Ichthyoplankton sampling can also be used for the prospection of new resources, establishing the timing and location of spawning areas and their variations, or estimating the relative abundance of different stocks and monitoring their abundance trends over time (Rodríguez et al. 2017). Furthermore, the nutritional condition of fish larvae is a reflection of environmental conditions to which they were exposed and is a useful tool to evaluate the physiological state of organisms. Monitoring the larval status over time allows the detection of areas and seasons favorable for the survival and growth of individuals. This information provides tools for the sustainable management of a population subject to fishing exploitation since it allows establishing appropriate fishing closure periods. One approach to studying the nutritional condition of larvae is the use of morphometric techniques. These methodologies are based on the fact that larvae in a deficient condition are typically thinner, have a lower weight for a given size and have an irregular body shape with respect to healthier individuals. Unhealthy larvae may experience higher mortality due to predation or due to the transportation to unfavorable areas (Theilacker 1978; Ferron and Leggett 1994; Suthers 1998). Therefore, the study of fish eggs and larvae is of extreme importance in any type of biological assessment of fisheries.

The Argentine anchovy E. anchoita is the most abundant fish species in the southwestern Atlantic Ocean, with a broad latitudinal distribution from $23^{\circ} \mathrm{S}$ to $47^{\circ} \mathrm{S}$ (Bakun 2006). There are two known stocks of this species in the Argentine Sea: the northern stock (also called Bonaerensis stock for being in the region of the Buenos Aires province) and the southern stock (or Patagonian stock, associated with the Patagonian region). The first one occurs between $34^{\circ} \mathrm{S}$ and $41^{\circ} \mathrm{S}$, and constitutes the most important group of pelagic fish of the region due to its biomass (Ciechomski and Sánchez 1988) and its trophic role as the main prey of other species of fish, mammals and seabirds (Angelescu 1982). During its reproductive peak in spring E. anchoita adults inhabit coastal waters, and anchovy eggs and larvae are found in temperatures between 9 and $23{ }^{\circ} \mathrm{C}$, with salinities greater than 23 (Reid 1966). Conditions of this area are suitable for the species reproduction during spring due to the water column stability and its trophic enrichment, both in nutrients and larval prey (Sánchez and Ciechomski 1995). Anchovy eggs and larvae are observed in the Buenos Aires region throughout the year, however there is a peak of abundance in spring and a secondary peak in autumn (Ciechomski and Sánchez 1984). 
The Estación Permanente de Estudios Ambientales (EPEA) is located at $38^{\circ} 28^{\prime} \mathrm{S}$ and $57^{\circ} 41^{\prime} \mathrm{W}$, approximately 27 nautical miles from Mar del Plata city, Buenos Aires Province (Figure 1). The EPEA is a fixed sampling station where plankton and environmental variables (physical and chemical) are studied over time since 2000. Several authors previously described in this location the existence of a seasonal cycle in temperature, concentration of chlorophyll- $a$ and abundance of zooplankton (Temperoni et al. 2011; Viñas et al. 2013). There are as well previous studies of anchovy larvae life traits and their relationship to the seasonality in that fixed sampling station. Leonarduzzi et al. (2010) analyzed the growths of anchovy larvae through their otolith microstructure and observed that the highest growth rate was recorded during spring in comparison to the remaining seasons. Sato et al. (2011) observed that the highest feeding incidence of anchovy larvae occurred during that same season. Do Souto et al. (2019), analyzing a shorter time period, detected lower growth rates and lower nutritional condition values through RNA/DNA indexes of anchovy larvae during winter. The use of morphometrical techniques allowed us to evaluate larval nutritional condition throughout a longer time series and this technique proved to be sensitive and complementary to other biochemical methodologies (Diaz et al. 2010). In addition to seasonality, fixed stations such as the EPEA allow the analysis of time series of physical and biological factors over long periods of time. This kind of analysis allows detecting patterns related to large temporal phenomena, such as the consequences of climate change.

The objective of this work was to estimate the density of eggs and larvae of E. anchoita and evaluate the nutritional condition of larvae using morphometric techniques in the search for seasonal patterns and trends over time within the period 2000-2017 at the EPEA.

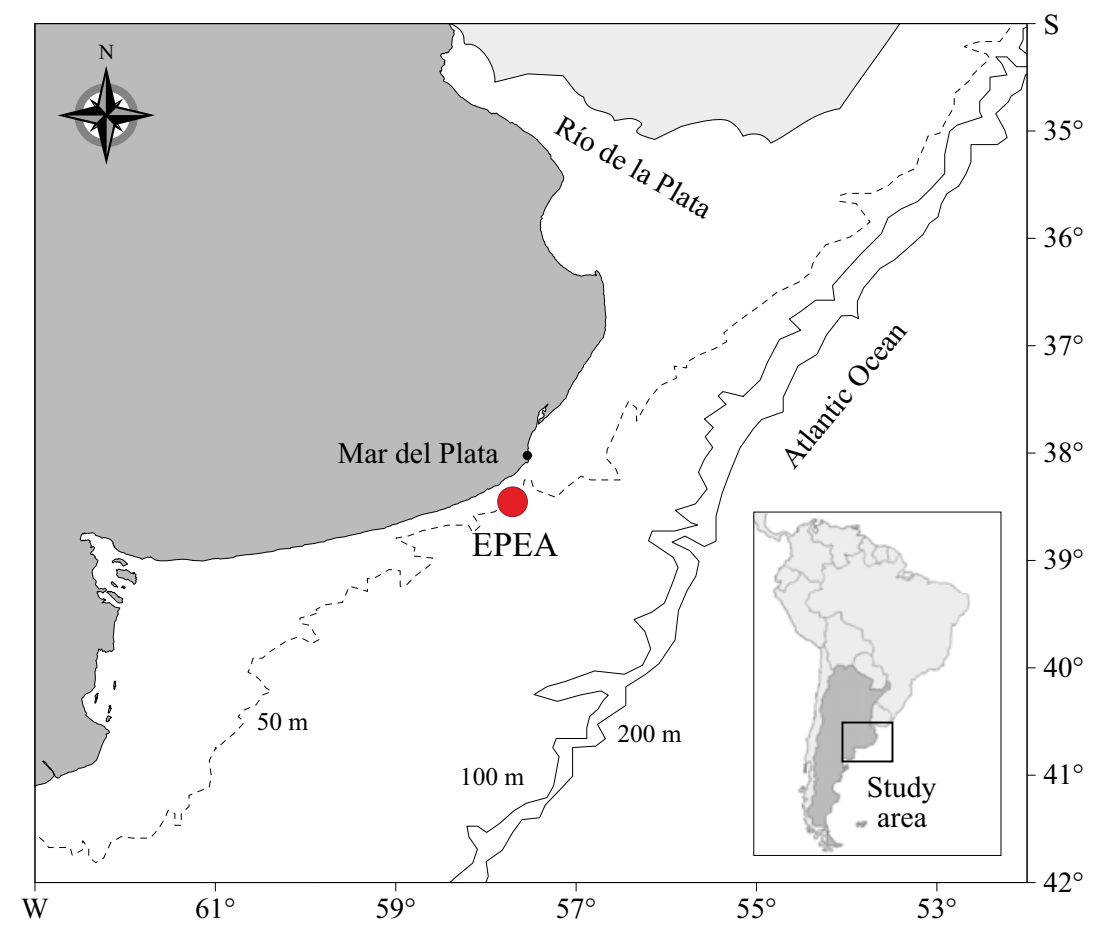

Figure 1. Estación Permanente de Estudios Ambientales (EPEA), $38^{\circ} 28^{\prime} \mathrm{S}-57^{\circ} 41^{\prime} \mathrm{W}$. 


\section{MATERIALS AND METHODS}

\section{Sample collection}

Samples were collected in 87 research surveys at the EPEA corresponding to the Marine Plankton Dynamics and Climate Change (DiPlaMCC) project of INIDEP, between February 2000 and November 2017 aboard different research vessels: BIP 'Capitán Cánepa', BIP 'Capitán Oca Balda', BIP 'Doctor Eduardo E. Holmberg', ARA 'Puerto Deseado' and oceanographic motor sailer 'Dr. Bernardo Houssay'. Eighty-seven plankton samples were collected by oblique trawls with a Bongo net, from $40 \mathrm{~m}$ depth (4 $\mathrm{m}$ above bottom) to the surface. The net was equipped with a mesh of $300 \mu \mathrm{m}$ and a flowmeter to estimate the volume of filtered water during the drag. Most of the samples were taken around noon. Immediately after the end of each tow, plankton samples were preserved in a $5 \%$ solution of formaldehyde in seawater.

\section{Sample processing and seasonal data analysis}

\section{Eggs and larvae densities}

Eggs and larvae of anchovy from each sample were identified in the laboratory according to the description given by Ciechomski (1967a) and counted under a binocular-dissecting microscope. Eggs $\left(\right.$ egg $\mathrm{m}^{-3}$ ) and larvae (ind. $\mathrm{m}^{-3}$ ) densities were estimated from the filtered volume of each sample. A mean density value was estimated for each month and season for the 2000 to 2017 period. Densities obtained for different seasons for the 2000 to 2017 period were compared using a Kruskall Wallis $\mathrm{K}$ nonparametric test, since data did not adjust to a normal distribution. Subsequently, a post hoc comparison test was performed to compare the densities of anchovy eggs and larvae for the four seasons using the Dunn's nonparametric test from the package PMCMRplus (Pohlert 2018). Densities of egg and larvae were graphed in relation to salinity and temperature values at $5 \mathrm{~m}$ depth. These physical data were obtained from the use of a SeaBird 19 CTD (conductivity-temperature-depth profiler) from surface to bottom in each survey. The $\mathrm{R}$ software version 3.3.2 (R Core Team 2016) was used for all the statistical analysis.

\section{Morphometry}

According to Diaz et al. (2009) variables recorded were: standard length (SL), head length (HL), head depth at the cleithrum level (HD), body depth posterior to the head (BD), body depth at the anus (BDA) and diameter of the eye (ED) (Figure 2). When the eye had an oval shape, ED was considered as the average between the maximum and minimum diameters recorded. Morphometric variables were recorded to the nearest micrometer with a Carl Zeiss stereoscope glass using Axio Vision software. No shrinkage corrections were made.

The BDA/SL ratio was determined for each specimen. Mean values per season were com-

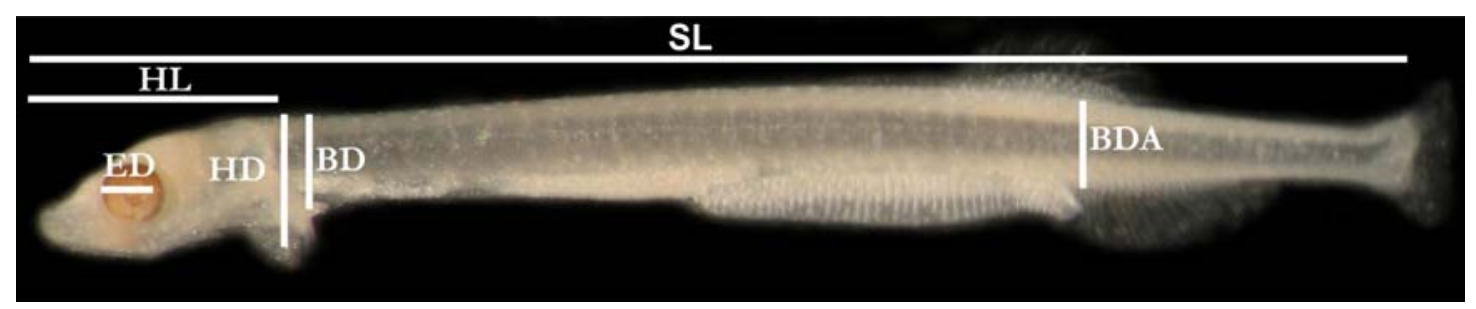

Figure 2. Engraulis anchoita larvae of $12 \mathrm{~mm}$ standard length. SL: standard length, HL: head length, HD: head depth at the cleithrum level, BD: body depth posterior to the head, BDA: body depth at the anus, ED: diameter of the eye. 
pared by ANOVA, followed by the Tukey test when significant differences were found. In order to determine if there were morphological differences among individuals from different seasons and among years, a Principal Component Analysis (PCA) was conducted to evaluate the relationship of all morphometric variables. Multivariate analysis represents one of the best techniques for studying nutritional condition since it allows the use of multiple variables registered on the same individual simultaneously. PCA is the only methodology that satisfies the requirements of an index of morphometric condition: independence of size, biological significance and orthogonality (McGurk 1985). Another advantage of this technique is that it allows the study of larvae captured in situ when their nutritional condition or stage of development is unknown (Cunha et al. 2003). Prior to PCA, variables were normalized by larval size according to equation 1 (Lleonart et al. 2000; Diaz 2010). This standardization method is based on the standardization of all morphometric variables obtained to a hypothetical reference size $\left(S L_{0}\right)$, taking into account allometric relationships between these variables and the standard length of the larvae, using a potential equation (equation 2). Thus, a particular observed data $\left(S L_{i} ; M V_{i}\right)$ becomes a theoretical value $\left(S L_{0} ; M V-N\right)$. This new normalized variable $(M V-N)$ is independent of the size of the individuals, so variations observed are due to their physical condition and not to their size.

Equation 1: normalized morphometric variable $\left(M V-N_{i}\right)$ :

$M V-N_{i}=M V_{i}\left[\frac{S L_{0}}{S L_{i}}\right]^{b}$

where $M V_{i}$ : value of a certain morphometric variable of the individual $i$ with a standard length $S L_{i}$; $S L_{0}$ : reference standard length (we defined $6 \mathrm{~mm}$ as reference size, since this was the mean standard length of the larvae); $b$ : allometric coefficient.
Equation 2: potential equation for the relationship between standard length (SL) and morphometric variables of specimens $(M V)$ :

$M V_{i}=a S L^{b}$

\section{Trends over time}

The method of analysis of time-series used in this work was developed according to the SCOR Global Comparisons of Zooplankton Time-series working group (WG125), the ICES Working Group on Zooplankton Ecology (WGZE), and the ICES Working Group on Phytoplankton and Microbial Ecology (WGPME). To avoid problems such as a strong seasonal cycle, calculation of a simple annual average from low frequency or irregular sampling (e.g. once per season, once per year) or missing months or gaps between sampling years, we used the technique of Mackas et al. (2001), in which the annual anomaly value (e.g. densities of anchovy eggs and larvae or $\mathrm{BDA} / \mathrm{SL}$ ratio) was calculated as the average of individual monthly anomalies within each given year. To accomplish this, the difference between each monthly value and the mean value for that year was first considered for each of the parameters (e.g. BDA/SL $\mathrm{SL}_{\text {August2000 }}$ - mean BDA/SL 2000 ). Secondly, its anomaly value was calculated for each year as the mean value of all its monthly anomalies. As this effectively removes the seasonal signal from the annual calculations, this method reduces many of the issues caused by using low-frequency and/or irregular monthly sampling to calculate annual means and anomalies (O'Brien et al. 2012). In the case of eggs and larvae densities, the log transformation was used to make highly skewed distributions less skewed. The Seasonal Kendall (SK) test, a non parametric test for seasonal data with serial dependence and missing data, was used to analyze the potential existence of a temporal trend in eggs and larvae densities and the ratio BDA/SL. The SK is an extension of the Mann-Kendall (MK) test pre- 
sented in Hirsch and Slack (1984). Although there are a variety of programs and libraries, such as trend (a library developed in $\mathrm{R}$ language where the Mann-Kendall test is implemented), they do not contemplate those cases in which there is missing data. For this statistical analysis, we used the csmk program developed in Fortram language (Hernández and Mendiolar 2018).

\section{RESULTS}

\section{Densities of eggs and larvae}

Monthly analysis of density of anchovy eggs for the considered period (2000-2017) showed that maximum average values occurred during the period October-December. These values var- ied between 17 and 24 egg $\mathrm{m}^{-3}$. Lowest monthly values were observed in January and in the AprilJune period. A secondary mode stood out in March with 9 egg $\mathrm{m}^{-3}$, in which a rarely high density of individuals was registered in a survey in 2005 , causing the average density of that month increase to $40 \mathrm{egg} \mathrm{m}^{-3}$ (Figure $3 \mathrm{~A}$ ).

As for the larvae, the main peak of average density was recorded in October $\left(6\right.$ ind. $\left.\mathrm{m}^{-3}\right)$, observing a secondary peak in May (4 ind. $\mathrm{m}^{-3}$ ). The highest density values of larvae were detected in October 2003 and 2006, with 23 and 16 ind. $\mathrm{m}^{-3}$, respectively. As observed with the eggs, larvae were detected throughout the year with the lowest density values in January and in the two-month period June-July (Figure $3 \mathrm{C}$ ).

Eggs and larvae densities from each survey were ordered according to the day of the year (DOY) they were sampled and (Figure $3 \mathrm{~B}$ and
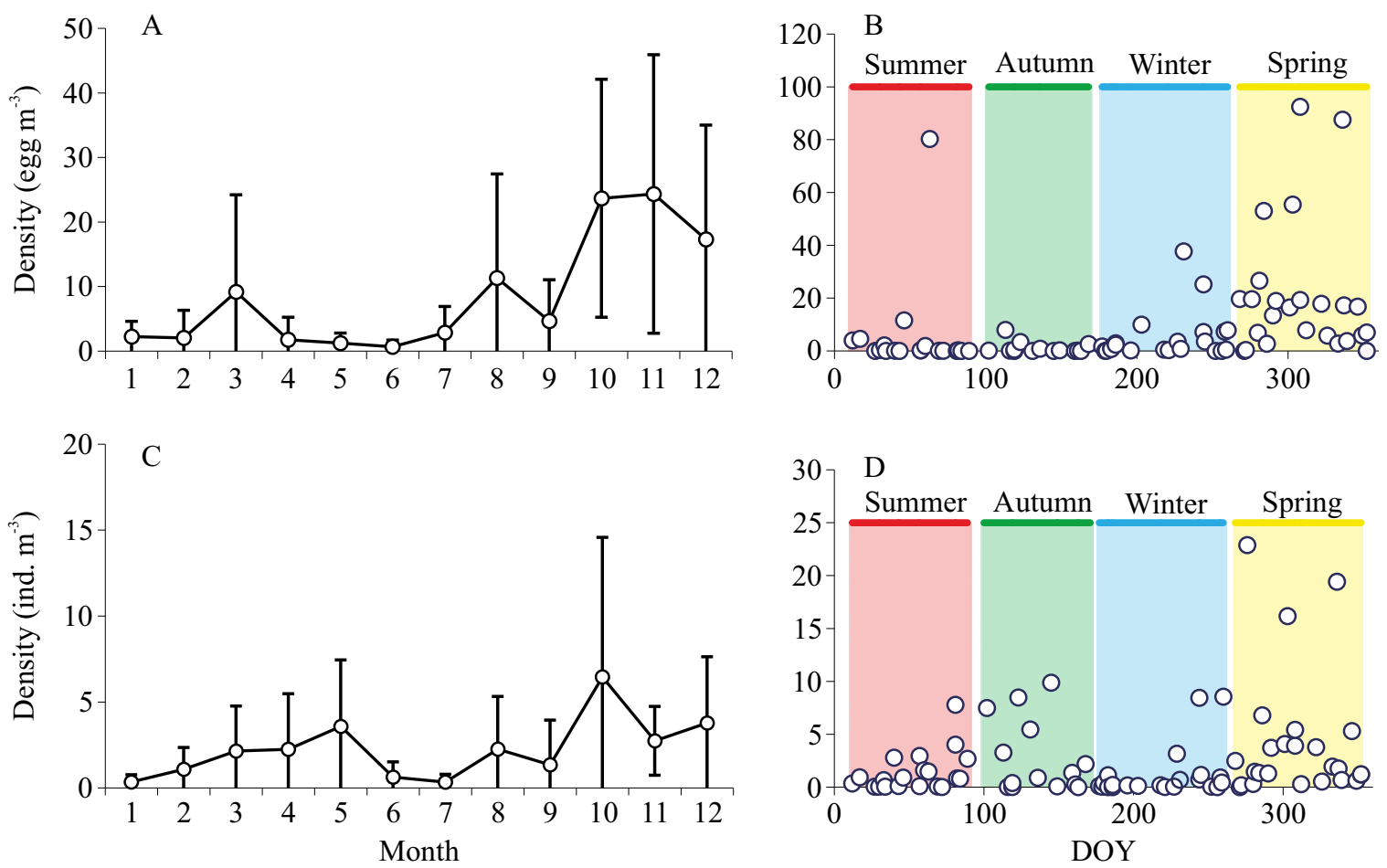

Figure 3. Average monthly densities (A and C) and densities according to the day of the year they were sampled (DOY) of Engraulis anchoita eggs (egg $\mathrm{m}^{-3}$ ) and larvae (ind. $\mathrm{m}^{-3}$ ) (B and D) detected in the Estación Permanente de Estudios Ambientales (EPEA). Vertical bars correspond to the standard deviation. 
D). The greatest abundance of eggs and larvae was recorded during spring, while there was a second minor peak of larval abundance during autumn. It was also observed that seasons with highest densities of eggs and larvae were also the seasons with greatest dispersion values. Seasonal analysis allowed us to observe statistical differences between the density of eggs $(K=23.69$, df $=3, \mathrm{p}<0.01)$ and larvae $(\mathrm{K}=10.71 ; \mathrm{df}=3 ; \mathrm{p}=$ 0.01 ) among the four seasons (Table 1). For instance, eggs density was higher in spring than in summer (Dunn test, $\mathrm{p}<0.015$ ) and in autumn (Dunn test, $\mathrm{p}<0.015$ ) (Table 1). A higher density of larvae was observed in spring than in winter (Dunn test, $\mathrm{p}<0.012$ ) (Table 1).

There was no clear trend between the density of egg and temperature and salinity (Figure 4). Physical parameters that determine the absence of eggs were not detected with clarity, however, the lowest densities of anchovy eggs were recorded at temperatures between $10{ }^{\circ} \mathrm{C}$ and $21^{\circ} \mathrm{C}$. Highest densities ( $>50 \mathrm{egg} \mathrm{m}^{-3}$ ) were observed in waters with salinities between 33.55 and 33.76 and $11.61{ }^{\circ} \mathrm{C}$ and $20.29^{\circ} \mathrm{C}$ of temperature. Similarly, larval abundance did not show a clear association with physical variables (Figure 5). How-

Table 1. A) Mean, standard deviation (SD) and median values of Engraulis anchoita eggs and larvae densities for each season during 2000-2017. B) Statistical comparison of pairs between the densities of E. anchoita eggs and larvae estimated at the EPEA for four seasons using the non-parametric Dunn's test. n.s.: non-significant differences, *: significant differences.

A

\begin{tabular}{lrrrrrrr}
\hline & \multicolumn{3}{c}{ Eggs } & & \multicolumn{3}{c}{ Larvae } \\
\cline { 2 - 3 } \cline { 6 - 7 } & Mean & SD & Median & & Mean & SD & Median \\
\hline Summer & 3.64 & 9.55 & 0.21 & & 1.34 & 1.88 & 0.82 \\
Autumn & 1.17 & 2.07 & 0.24 & & 2.02 & 2.95 & 0.40 \\
Winter & 6.02 & 9.63 & 1.81 & & 1.45 & 2.48 & 0.32 \\
Spring & 19.34 & 18.53 & 14.95 & & 4.42 & 7.77 & 2.60 \\
\hline
\end{tabular}

B

\begin{tabular}{|c|c|c|c|c|}
\hline & \multicolumn{2}{|c|}{ Eggs } & \multicolumn{2}{|c|}{ Larvae } \\
\hline & Dunn's test & p-value & Dunn's test & p-value \\
\hline Summer-Autumn & 2.30 & $>0.05$ n.s. & 0.21 & $>0.05$ n.s. \\
\hline Summer-Winter & 13.03 & $>0.05$ n.s. & 3.58 & $>0.05$ n.s. \\
\hline Summer-Spring & -30.61 & $<0.001^{*}$ & -17.80 & $>0.05$ n.s. \\
\hline Autumn-Winter & -15.33 & $>0.05$ n.s. & 3.37 & $>0.05$ n.s. \\
\hline Autumn-Spring & -32.92 & $<0.001^{*}$ & -18.01 & $>0.05$ n.s. \\
\hline Winter-Spring & -17.58 & $>0.05$ n.s. & -21.38 & $<0.05^{*}$ \\
\hline
\end{tabular}




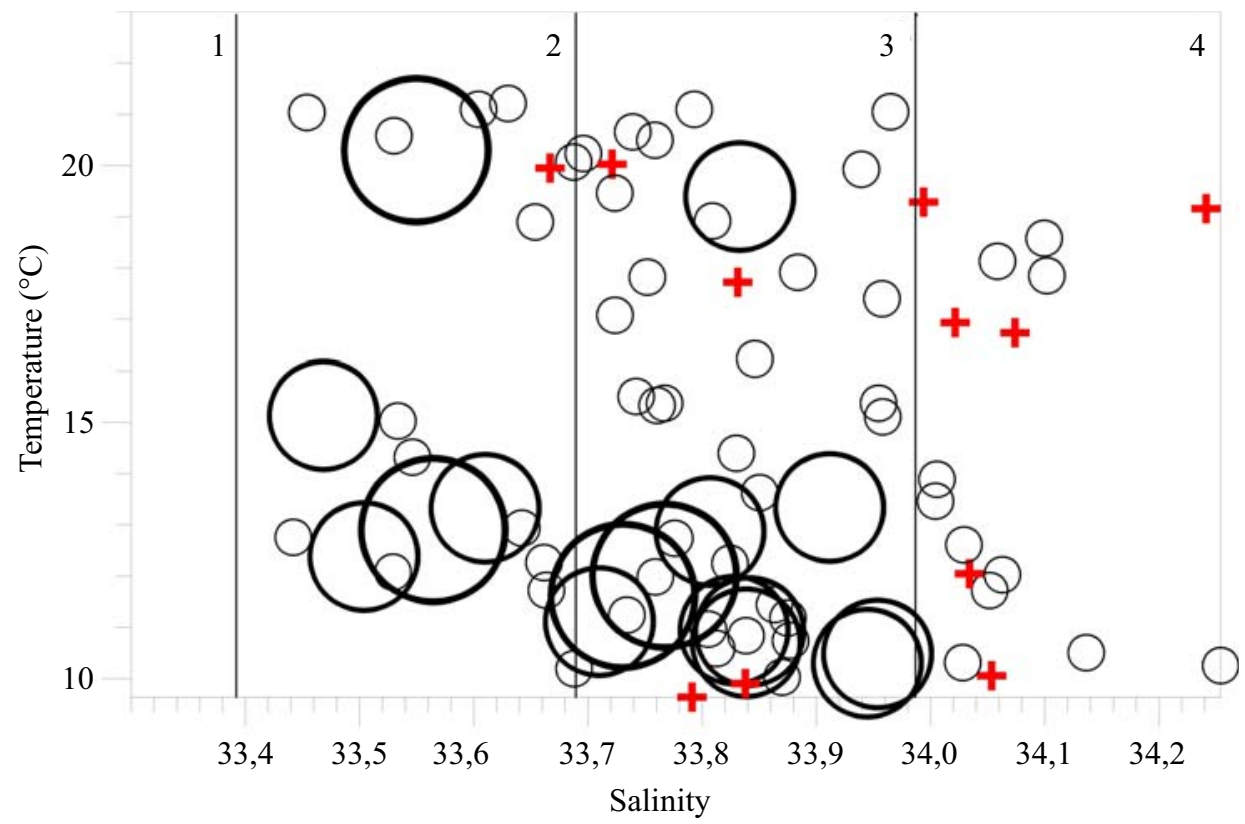

Figure 4. Density of Engraulis anchoita eggs at the Estación Permanente de Estudios Ambientales (EPEA). Crosses represent stations with no eggs. Larger circles indicate 50-100 egg $\mathrm{m}^{-3}$. Numbers 1 to 4 represent the type of water mass (Martos et al. 2005). 1: coastal waters of low salinity, 2: medium shelf waters, 3: coastal waters with high salinity, 4: waters of maximum salinity.

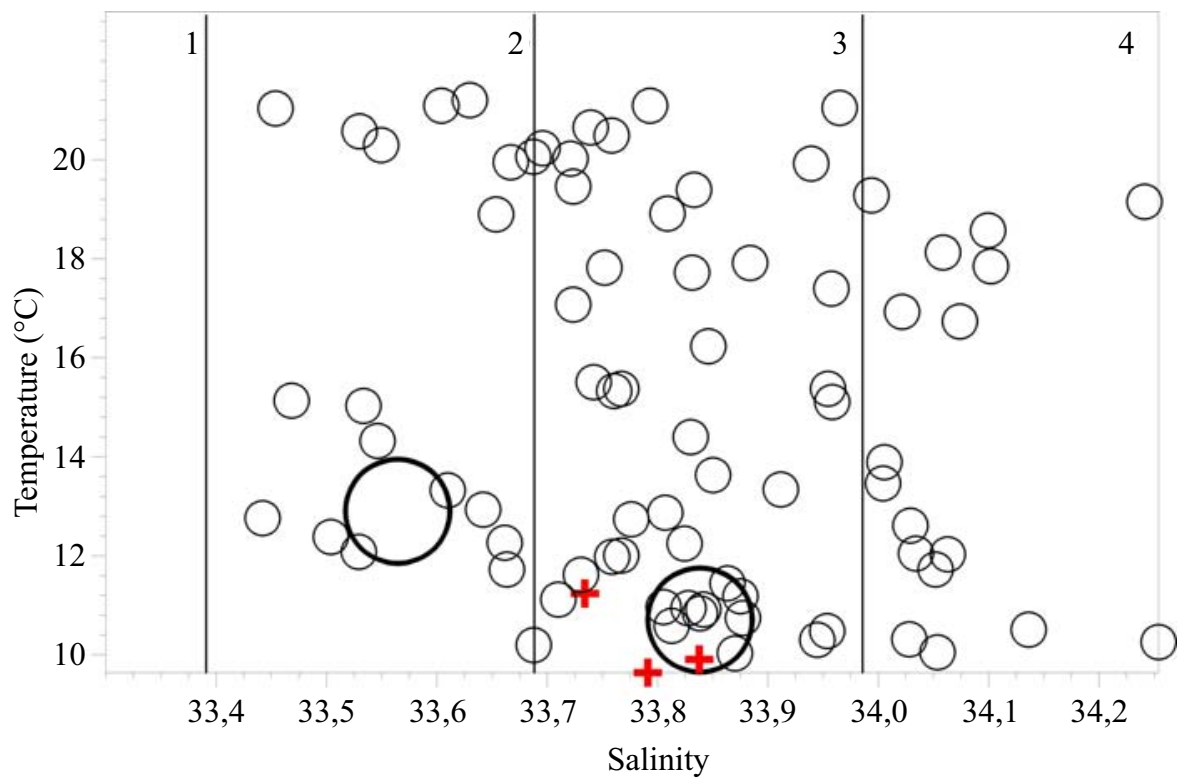

Figure 5. Engraulis anchoita larval density at the Estación Permanente de Estudios Ambientales (EPEA). Crosses represent stations with no larvae. Larger circles indicate 10-50 ind. $\mathrm{m}^{-3}$. Numbers 1 to 4 represent the type of water mass (Martos et al. 2005). 1: coastal waters of low salinity, 2: medium shelf waters, 3 : coastal waters with high salinity, 4: waters of maximum salinity. 
ever, highest larval densities (between 8.24 and 22.8 ind. $\mathrm{m}^{-3}$ ) were detected between salinities of 33.56 and 33.95 , a range similar to that observed for highest eggs densities. Regarding temperature, highest densities were registered between 10.19 and $16.23{ }^{\circ} \mathrm{C}$, presenting a narrower thermal range than eggs.

\section{Morphometry}

Larvae with larger size range were found in autumn (ANOVA: $\mathrm{F}=72.27 ; \mathrm{n}=1,367 ; \mathrm{p}<$ 0.001 ) (Figure 6). The SL of larvae collected during autumn varied between 2.56 and $23.55 \mathrm{~mm}$, with a mean value of $7.55 \pm 3.19 \mathrm{~mm}(\mathrm{n}=438)$. Sizes recorded during spring varied between 2.75 and $14.01 \mathrm{~mm} \mathrm{SL}$, with an average of $5.30 \pm 2.10$ $\mathrm{mm} \mathrm{SL}(\mathrm{n}=441)$. In winter, SL of larvae ranged between 2.59 and $15.67 \mathrm{~mm}$ and averaged $5.65 \pm$ $2.36 \mathrm{~mm}(\mathrm{n}=276)$. Finally, in summer larvae had a range of sizes between 2.56 and $12.36 \mathrm{~mm}$ and an average of $5.27 \pm 2.03 \mathrm{~mm}(\mathrm{n}=212)$.

Main values of BDA/SL ratio presented significant differences among seasons (ANOVA: $\mathrm{F}=$
$73.67 ; \mathrm{n}=1,367 ; \mathrm{p}<0.001$; Table $2 \mathrm{~A})$. The average value obtained for larvae captured during autumn was significantly higher than those corresponding to other seasons. On the other hand, this mean value ratio was the lowest in the larvae captured in winter (Tukey test $\mathrm{p}<0.05$, Table $2 \mathrm{~A}$ ). An upward trend in the $\mathrm{BSA} / \mathrm{SL}$ ratio was observed in autumn and spring and a downward trend in winter with respect to the advance of the seasons (Figure 7).

The body condition of anchovy larvae was analyzed through a PCA along the period studied (Figure 8). Morphometric variables were standardized to a reference size of $6 \mathrm{~mm}$ before PCA. The first two main components of the analysis explained $90 \%$ of the variability observed (Table 2 B). Variables that positively characterized PC1 were body widths (BD and BDA), head length and diameter of the eye. Body widths are the variables most related to the condition and those that explained most of the variability observed for the first principal component. The PC2 was explained positively by the height of the body at the anus level, head depth and the diameter of the

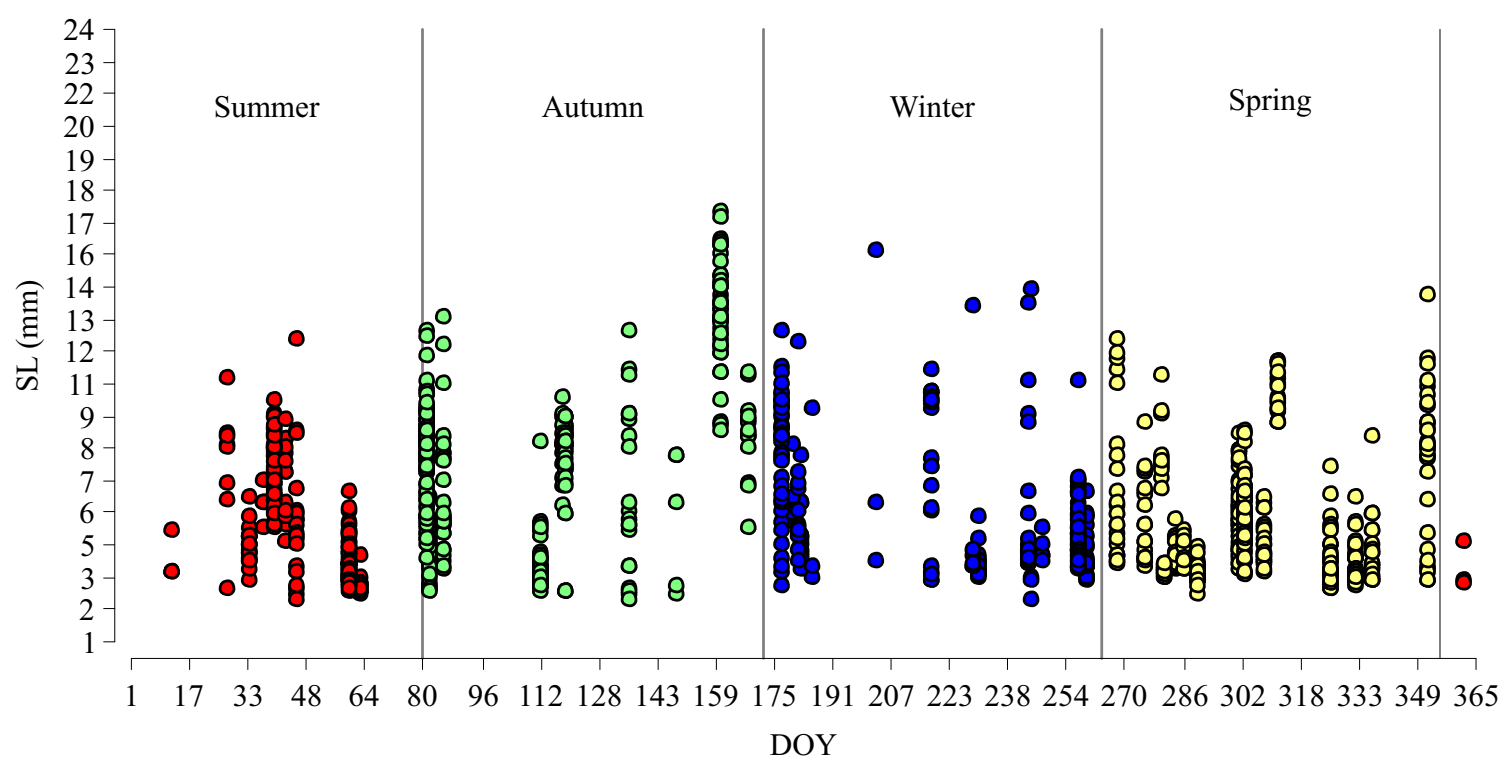

Figure 6. Distribution of larval sizes of Engraulis anchoita per day of the year (DOY) during 2003-2017 at the Estación Permanente de Estudios Ambientales (EPEA). Seasons are indicated. 
Table 2. A) Analysis of variance to compare seasonal mean values of the BDA/SL ratio for Engraulis anchoita larvae and Tukey post hoc test. B) Eigenvalues and eigenvectors obtained in the Principal Component Analysis using normalized morphometric variables recorded in $E$. anchoita larvae. Mean BDA/SL per season \pm standard error, and number of samples between brackets; capital letters indicate significant differences in the Tukey test. Data corresponded to 2003-2017 at the Estación Permanente de Estudios Ambientales (EPEA). HL: head length, HD: head depth at the cleithrum level, BD: body depth posterior to the head, BDA: body depth at the anus, ED: diameter of the eye. -N: indicates that morphometric variables were normalized.

A

\begin{tabular}{lrrrrrl}
\hline & SS & df & MS & F & p-value & Mean BDA/SL per season \\
\hline Model & 0.01 & 3 & $3.6 \mathrm{E}-03$ & 60.66 & $<0.0001$ & Winter 0.0511 $\pm 4.9 \mathrm{E}-04(246)^{\mathrm{A}}$ \\
Season & 0.01 & 3 & $3.6 \mathrm{E}-03$ & 60.66 & $<0.0001$ & Spring 0.0536 $\pm 3.8 \mathrm{E}-04(412)^{\mathrm{B}}$ \\
Error & 0.07 & 1,203 & $5.9 \mathrm{E}-05$ & & & Summer 0.0562 $\pm 5.3 \mathrm{E}-04(212)^{\mathrm{B}}$ \\
& & & & & & \\
\hline Total & 0.08 & 1,206 & & & & \\
\hline
\end{tabular}

B

Eigenvalues

\begin{tabular}{lccclrrrr}
\hline Lambda & Value & Proportion & Cumulative proportion & & Variables & PC1 & PC2 & PC3 \\
& & & & & & & & \\
1 & 3.46 & 0.69 & 0.69 & HD-N & -0.38 & 0.58 & 0.56 \\
2 & 1.02 & 0.20 & 0.90 & BD-N & 0.48 & -0.28 & 0.49 \\
3 & 0.52 & 0.10 & 1.00 & BDA-N & 0.47 & 0.37 & 0.41 \\
4 & 0.00 & 0.00 & 1.00 & HL-N & 0.53 & -0.09 & -0.07 \\
5 & 0.00 & 0.00 & 1.00 & ED-N & 0.35 & 0.66 & -0.52 \\
\hline
\end{tabular}

eye, and negatively by body widths and head length. The PCA revealed that the larvae collected in autumn and summer were characterized by larger body widths.

On the other hand, PC3 explained $10 \%$ of the variability observed (Figure 9). In all biplot graphs larvae collected in winter were characterized by the lowest magnitudes in all variables. In this way, it could be considered that in this season they would be in a poorer nutritional condition compared to larvae collected in other seasons of the year.

\section{Trends over time}

Anchovy eggs and larvae did not show a significant temporal trend in their anomalies of abundance within the studied period (Figure $10 \mathrm{~A}$ and $\mathrm{B}$, SK test $\mathrm{p}=0.26$ and $\mathrm{p}=0.35$ to eggs and larvae, respectively). Finally, anomalies of the $\mathrm{BDA} / \mathrm{SL}$ ratio obtained for anchovy larvae did not show a significant temporal trend within the studied period (Figure $10 \mathrm{C}$, SK test $\mathrm{p}=0.56$ ). 

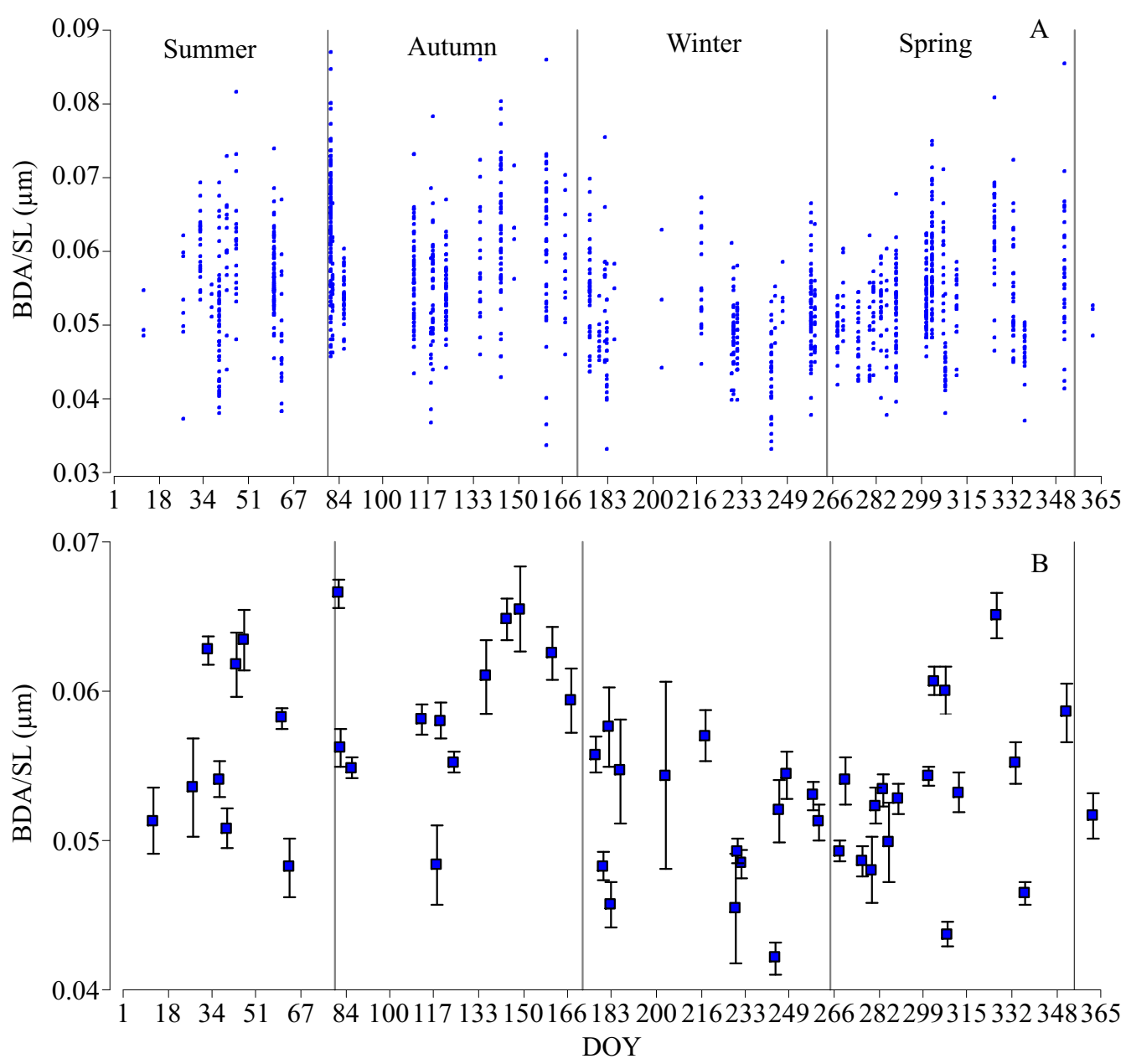

Figure 7. Variation of BDA/SL ratio per day of the year (DOY) of Engraulis anchoita larvae. A) Data is shown per individual.

B) Mean value per day of the year with corresponding standard deviations. Data obtained during 2003-2017 at the Estación Permanente de Estudios Ambientales (EPEA). Seasons are indicated.

\section{DISCUSSION}

\section{Densities of eggs and larvae}

In the present study, characteristics of the early life history of $E$. anchoita were evaluated during almost two decades of data, considering possible variations related to seasonality and the existence of a trend over time. Eggs and larvae density values of this species recorded in the present study were consistent with those reported in previous works (Ciechomski 1969; Ciechomski et al. 1981; Ciechomski and Booman 1983; Sánchez 1995). Sánchez (1995) carried out a detailed monthly analysis of the spawning activity of this species and detected an extraordinary expansion of the reproductive activity in October covering the entire shelf of Buenos Aires Province, and reaching the maximum peak of eggs and larvae densities in the period October-November. A maximum spawning activity was detected during spring (October- 


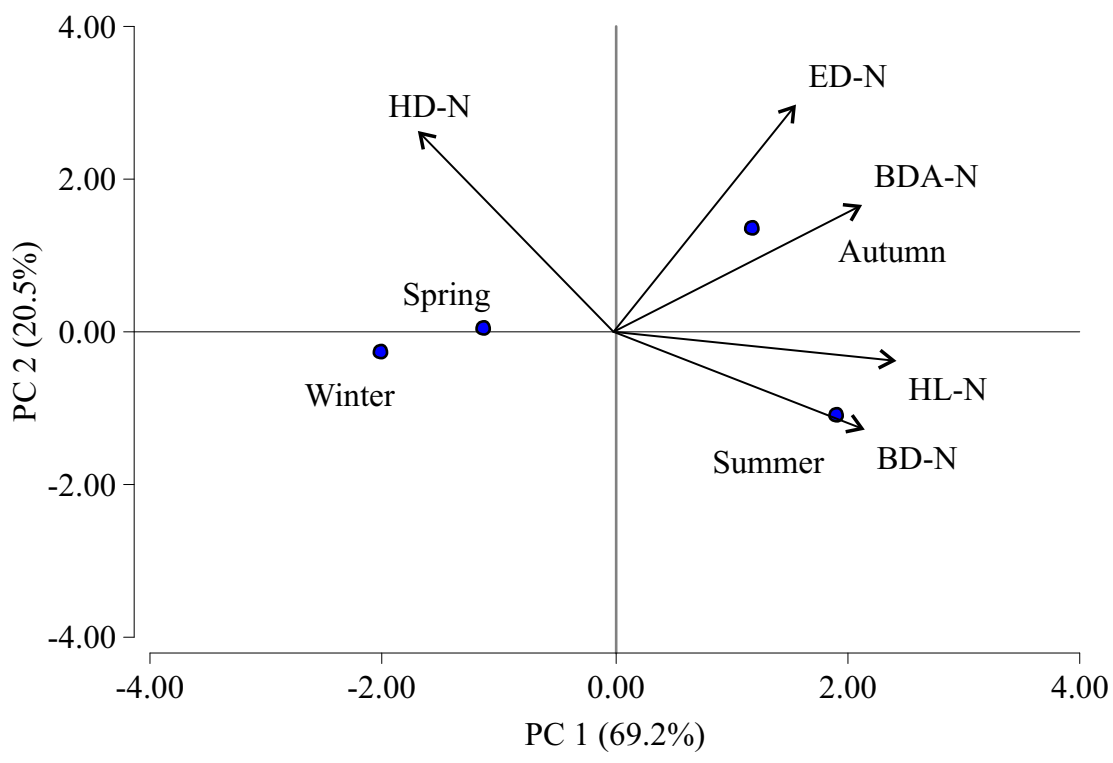

Figure 8. Biplot graph of the first two principal components (PC) obtained through Principal Component Analysis employing morphometric variables of Engraulis anchoita larvae. Vectors indicate the direction and rate of change of each variable. Data were grouped by season (blue circles). Data were obtained during 2003-2017 at the Estación Permanente de Estudios Ambientales (EPEA). HL: head length, HD: head depth at the cleithrum level, BD: body depth posterior to the head, BDA: body depth at the anus, ED: diameter of the eye. $-\mathrm{N}$ : indicates that morphometric variables were normalized.

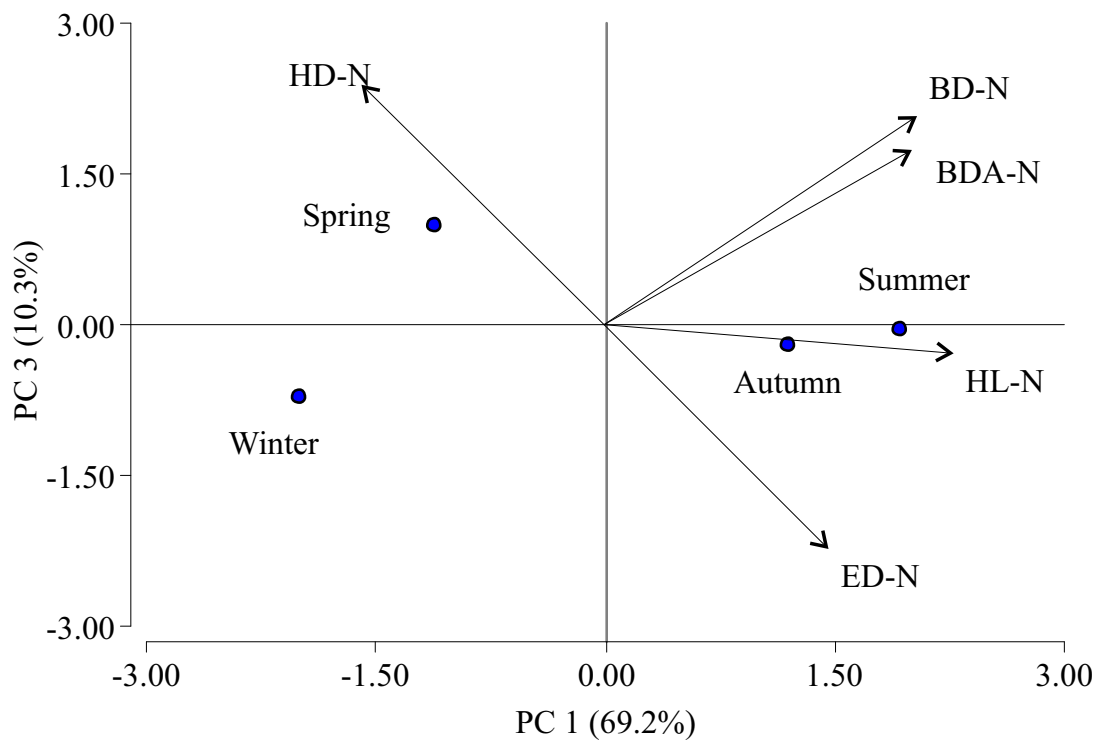

Figure 9. Biplot graph of principal components (PC) 1 and 3 obtained from the Principal Component Analysis of morphometric variables of Engraulis anchoita larvae. Vectors indicate the direction and rate of change of each variable. Data were grouped by season (blue circles). Data were obtained during 2003-2017 at the Estación Permanente de Estudios Ambientales (EPEA). HL: head length, HD: head depth at the cleithrum level, BD: body depth posterior to the head, BDA: body depth at the anus, ED: diameter of the eye, $-\mathrm{N}$ : indicates that the morphometric variables were normalized. 

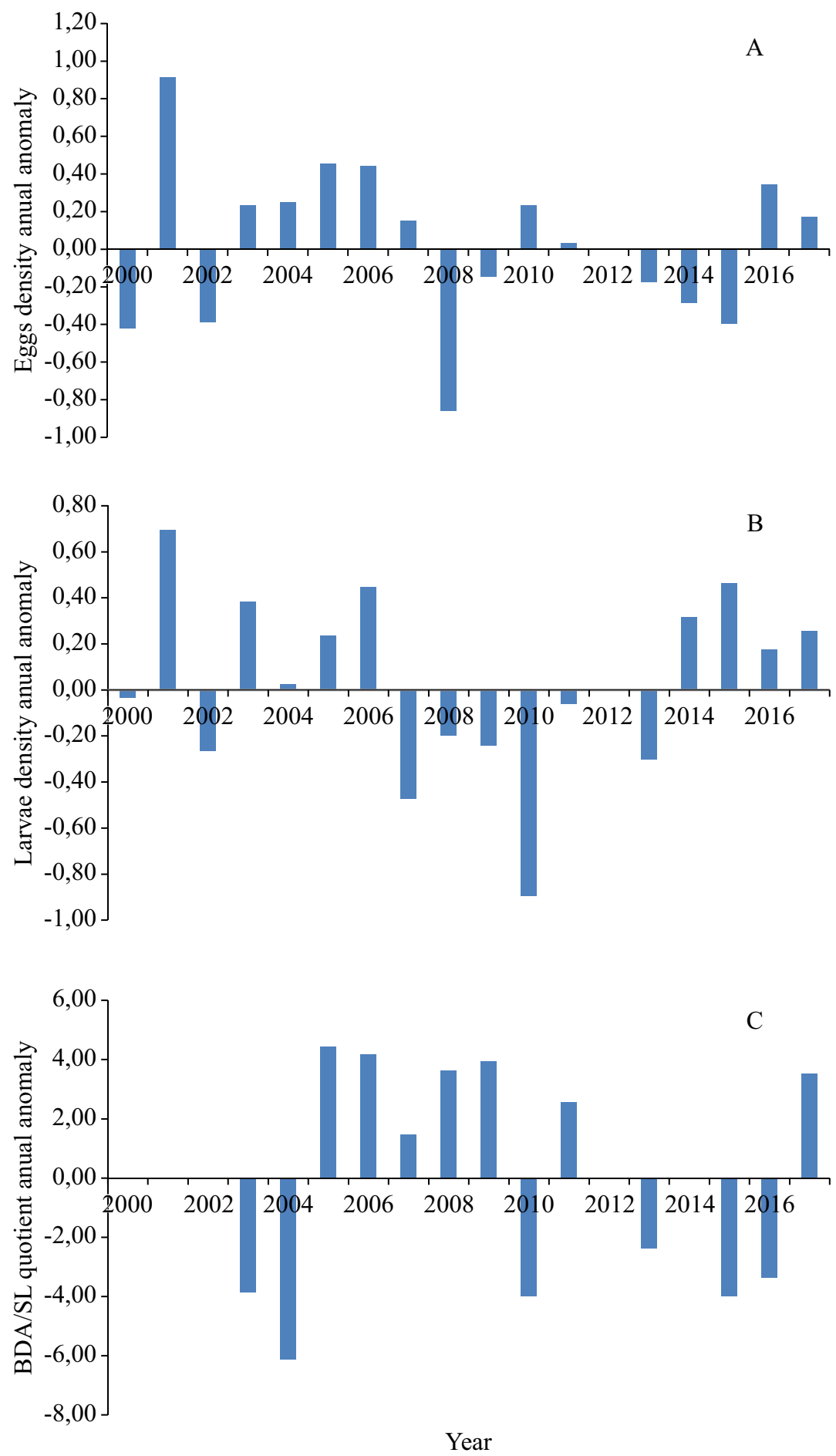

Figure 10. Anomalies of Engraulis anchoita, egg abundance (A), larvae (B), and BDA/SL ratio (C) between 2000 and 2017 at the Estación Permanente de Estudios Ambientales (EPEA). 
December) at the EPEA, and a secondary one in late summer-early autumn period, which seems to be related to the secondary anchovy peak observed in autumn-winter. Although restricted to October, the density of anchovy larvae also had a maximum peak during spring and a secondary mode in March-May, somewhat shifted in time with respect to the secondary mode of eggs density. Results obtained at the EPEA are similar to those indicated by Sánchez (1995), except for the great abundance of eggs and larvae found during winter in this present work. This difference could be due to the high densities registered in August 2004 and August 2010, typical of spring time.

South of $37^{\circ} \mathrm{S}$, the distribution of anchovy eggs and larvae has been related to the position of a surface thermal front (Pájaro et al. 2008). This front separates homogeneous coastal waters from stratified waters of the middle shelf regime in the vicinity of the 40-50 $\mathrm{m}$ isobaths, where the EPEA is located. During years in which the position of the front moves towards deep waters or is absent, lower densities of eggs and larvae have been observed. On the contrary, in years when the frontal system was strong, densities of anchovy eggs and larvae were higher (Pájaro et al. 2008). Therefore, differences in the formation and position of the front could be the cause of changes in the abundance of eggs and larvae at the EPEA.

The inter-annual variation of eggs was very high in seasons with the most intense spawning. This may be related to the fact that the distribution of anchovy eggs and larvae is highly contagious (Sánchez 1986). Therefore, this variation could be due to a methodological problem, since in some cases the sampling could have been done in the center of the patch of organisms, and sometimes it could have carried out in its periphery. However, to maximize the catchability of eggs and larvae, samples were collected from near the bottom $(40 \mathrm{~m})$ to the surface, since the relatively close-to-surface distribution observed for $E$. anchoita larvae seems typical of Clupeiforms
(Matsuura et al. 1992; Matsuura and Kitahara 1995; Castro et al. 2000; Spinelli et al. 2013; Torquato and Muelbert 2014).

The lowest abundance of anchovy eggs was detected in autumn, with statistical differences between that season and spring. However, when analyzing the larvae, no differences were found between autumn and winter-spring, and the average autumn densities were even higher than those of summer and winter. This could indicate that the survival of larvae born in autumn would be higher than that of larvae hatched in other seasons of the year. However, to understand the cause of this phenomenon other studies will be necessary, including the abundance of food zooplankton throughout the year and the presence of predators. Several studies correlated egg and larval abundance to zooplankton biomass (Viñas et al. 2002; Twatwa et al. 2005; Somarakis and Nikolioudakis 2007; Zarrad et al. 2012; Malavolti et al. 2018). For example, a significant relationship was found between the abundance of small copepods and the abundance of anchovy eggs during the spring in the coastal area of Buenos Aires Province (Viñas et al. 2002). This relationship could have trophic implications as these small copepod species produce eggs and nauplii in the optimum size range of prey for first-feeding anchovy larvae (Viñas and Ramírez 1996). Future integrative analyses have to be performed to understand whether spawning of E. anchoita in the EPEA area, with high zooplankton concentrations, provides better conditions to larval survival.

In this study we observed a wide range of temperatures and salinities in which anchovy eggs and larvae occurred, as previously indicated by Ciechomski (1967b), Brewer (1976), Matsuura and Kitahara (1995) and Torcuato and Muelbert (2014). We did not find a clear pattern of egg and larvae densities in relation to temperature or salinity suggesting that thermal tolerance enables larvae to exploit different habitats or seasons (Matsuura et al. 1992; Torcuato and Muelbert 2014). On the Buenos Aires shelf (south of $37^{\circ} \mathrm{S}$ ), there 
is a middle shelf front near the $50 \mathrm{~m}$ isobath, which separates vertically homogeneous coastal waters from stratified waters of the middle shelf (Lucas et al. 2005; Martos et al. 2005). Conditions of most of the surveyed water masses corresponded to coastal waters of high salinity, and to a lesser extent to those of the medium shelf. Associated with these two water masses, the highest densities of anchovy eggs and larvae were detected. Auad and Martos (2012), through in situ data analysis and numerical modeling for the period 1993-2008, determined that the intensity of the front, the flow along the coast, and the abundances of anchovy larvae would be connected and forced by the effort of the wind along the coast.

These results are particularly interesting especially when considering inter-annual variations, and they might explain the abrupt changes in recruitment observed from one year to another. In the past, biomass fluctuations from one to six million tons have been detected to the northern stock of the species (Hansen 2004). For this reason, it is emphasized the importance of time series to detect how anchovy responds to possible environmental variations resulting from climate change. In general, surface layers of the oceans have progressively increased their temperature in recent decades, with an important effect on the distribution and reproduction of marine species (Edwards and Richardson 2004; Richardson and Schoeman 2004). To detect these effects, it is essential to have time series of data that reflect these changes. On the other hand, variations in the average temperature of seawater can result in movements of peaks of secondary production, resulting in a decoupling with the peak of larval production and therefore affecting the survival of the first stages of development of fish.

\section{Morphometry}

Morphometric techniques represent a simple methodology that does not require sophisticated or expensive equipment, and has a great potential for studying the nutritional condition of fish larvae (Diaz et al. 2009). This methodology is based on the fact that thin larvae with an irregularly shaped body are regarded to be in poor condition (Ferron and Leggett 1994). Moreover, body height includes, among other structures, the height of the digestive tract and the liver, tissues that have been shown to be highly sensitive to the larval condition (Theilacker 1978). One of the main limitations of morphometric techniques is the dependence on the size of the larvae, which provides a source of additional variability that overlaps with the effects of starvation on the studied variables. Removal of the size effect can be accomplished by applying mathematical transformations or limiting the size range (Suthers 1998). To solve this problem, morphometrical variables were normalized in this study following Leonart et al. (2000) and Diaz (2010). This method relativizes recorded variables of all individuals to the same size and thus morphological differences are due solely to the condition of the specimens regardless of their size.

PCA results indicated that larvae obtained in winter were characterized by lower values of body widths (BD and BDA), variables directly related to the nutritional condition (Diaz et al. 2009). Additionally, the average winter BDA/SL ratio was significantly lower than those in other seasons. Even though a great individual variability among larvae was observed, it can be assumed that larvae collected in winter are in a poorer nutritional condition with respect to those obtained in other seasons. In contrast, mean BDA/SL obtained for larvae collected during autumn was the highest recorded among seasons. Furthermore, it was observed that the BDA/SL ratio obtained for larvae collected in spring was more variable than that corresponding to the larvae collected in autumn. Studying larvae of the same species in 'El Rincón' area (an estuarine environment close to our study area), Diaz et al. (2009) found a reduction in the nutritional condition of individuals when larval densities were 
extremely high. Similarly, density-dependent factors could be acting at the EPEA during spring that would lead to a somewhat poorer nutritional condition when a temporal coincidence of high larval densities and moderate or low concentrations of larval prey is observed. Using the RNA/DNA condition index, Do Souto et al. (2019) also observed that the larval condition of E. anchoita was significantly lower during the winter period 2009-2017. In accordance with the results herein presented, these same authors established that autumn and spring would be the most favorable seasons for the growth and condition of anchovy larvae at the EPEA. Do Souto et al. (2019) coincidentally observed that RNA/DNA index presented less variability during autumn in comparison to spring. On the contrary, low larval growth rates, as well as poor nutritional condition, would indicate that winter represents an unfavorable period for the anchovy larvae.

\section{Trends over time}

We did not observe significant trends over time in densities of early developmental stages of anchovy or in the nutritional condition of larvae within the studied period. This may be because the number of samples analyzed was too small to show long-term patterns. These results reinforce the need to maintain this time series and analyze a longer period of time in the future. Long-term study of anchovy abundances and nutritional condition will allow evaluating the possible effect of climate change on the early ontogeny of this species.

The importance of this type of studies lies in the fact that it allows determining the existence of favorable areas for the growth and survival of larvae, providing tools for the comprehensive management of a population subjected to fishing exploitation. Although E. anchoita represents at present an underexploited resource, it has great fishing potential for the future (Madureira et al. 2009). Interdisciplinary studies are needed in order to deepen the knowledge about this pelagic species particularly vulnerable to environmental variations resulting from climate change. The only way to assess the impact of climate change on natural planktonic communities is by making continuous long-term observations. At the moment few observations are maintained frequently enough to respond to possible changes in these communities over time attributable to climate change. The synchrony in the growth cycle of phytoplankton-zooplankton-larval hatching (strongly affected by the environment) is critical in the life of fish (Hjort 1914; Cushing 1969, 1990; Sinclair and Tremblay 1984). Therefore, modification of plankton communities and their interactions, strongly affected by the climate change, could have dramatic socioeconomic impacts through the effects on species of commercial interest, exacerbating the impact of overfishing (Beaugrand et al. 2003).

\section{ACKNOWLEDGEMENTS}

The authors express their gratitude to the staff belonging to the Project "Marine Plankton Dynamics and Climate Change" for all kinds of collaboration provided during research and material processing, to the authorities of the INIDEP and onboard personnel. Special thanks to the "Dr. Bernardo Houssay" captain and crew. INIDEP contribution no 2238 .

\section{REFERENCES}

Angelescu V. 1982. Ecología trófica de la anchoíta del Mar Argentino (Engraulidae, Engraulis anchoita). Parte II. Alimentación, comportamiento y relaciones tróficas en el ecosistema. Contrib Inst Nac Invest Desarr Pesq (Mar del Plata). No 409. 83 p. 
Auad G, Martos P. 2012. Climate variabilityof the Northern Argentinean Shelf Circulation: impact on Engraulis anchoita. Int J Ocean Climate Syst. 3 (1): 17-43. doi:10.1260/17593131.3.1.17

BAKUN A. 2006. Wasp-waist populations and marine ecosystem dynamics: navigating the "predator pit" topographies. Prog Oceanogr. 68: 271-288.

Beaugrand G, Brander KM, Lindley JA, Souissi S, REID PC. 2003. Plankton effect on cod recruitment in the North Sea. Nature. 426: 661-664.

BREWER GD. 1976. Thermal tolerance and resistence of the northern anchovy Engraulis mordax. Fish Bull US. 74: 1- 8.

Castro LR, Salinas GR, Hernández EH. 2000. Environmental influences on winter spawning of the anchoveta Engraulis ringens off Central Chile. Mar Ecol Prog Ser. 197: 247-258.

Ciechomski JD. 1967a. Present state of the investigations on the Argentine Anchovy Engraulis anchoita (Hubbs, Marini). Cal Coop Ocean Fish. 11: 58-66.

Ciechomski JD. 1967b. Influence of some environmental factors upon the embryonic development of the Argentine anchovy Engraulis anchoita. Cal Coop Ocean Fish. 11: 67-71.

Ciechomski JD. 1969. Investigaciones sobre la distribución de huevos de anchoíta frente a las costas argentinas, uruguayas y sur del Brasil; resultados de nueve campañas oceanográficas, agosto 1967-julio 1968. FAO Proy Desarr Pesq. Ser Inf Téc. 14: 1-10.

Ciechomski JD, Booman CI. 1983. Distribución cuantitativa de huevos y larvas de anchoíta (Engraulis anchoita) en la plataforma continental, frente a las costas de la Argentina y Uruguay en el ciclo anual 1981/1982. Contrib Inst Nac Invest Desarr Pesq (Mar del Plata). $\mathrm{N}^{\mathrm{o}} 431.14 \mathrm{p}$.

Ciechomski JD, Ehrlich MD, LAsta CA, SÁnCHEZ RP. 1981. Distribución de huevos y larvas de peces en el Mar Argentino y evalu- ación de los efectivos de desovantes de anchoíta y de merluza. Contrib Inst Nac Invest Desarr Pesq (Mar del Plata). No 383. 20 p.

Ciechomski JD, SÁnchez RP. 1984. Field estimates of embryonic mortality of Southwest Atlantic anchovy (Engraulis anchoita). Meeresforschung. 30: 172-187.

Ciechomski JD, SÁNchez RP. 1988. Análisis comparativo de las estimaciones de biomasa de la anchoíta (Engraulis anchoita) en el Atlántico Sudoccidental en diferentes años y con distintas metodologías. Publ Com Téc Mix Fr Mar. 4. 14 p.

Cunha I, Saborido-Rey F, Planas M. 2003. Use of multivariate analysis to assess the nutritional condition of fish larvae from nucleic acids and protein content. The Biol Bull. 204: 339349.

CusHING DH. 1969.The regularity of the spawning season of some fishes. J Cons Int Explor Mer. 33: 81-92.

CUSHING DH. 1990. Plankton production and year-class strength in fish populations: an update of the match/mismatch hypothesis. In: BlaXter JHS, SOUTHWARD AJ, editors. Advances in marine biology. San Diego: Academic Press Limited. p. 250-313.

DiAz MV. 2010. Análisis espacio-temporal del estado nutricional de larvas de anchoíta Engraulis anchoita. Relación con las características hidrográficas y la disponibilidad de alimento [PhD thesis]. Buenos Aires: Facultad de Ciencias Exactas y Naturales, Universidad de Buenos Aires. 282 p.

DiAz MV, PÁJARo M, SÁNChez RP. 2009. Employment of morphometric variables to assess nutritional condition of Argentine anchovy larvae Engraulis anchoita Hubbs \& Marini, 1935. Rev Biol Mar Oceanog. 44: 539-549.

Do Souto M, Brown DR, Leonarduzzi E, Capitanio F, Diaz MV. 2019. Nutritional condition and otolith growth of Engraulis anchoita larvae: the comparison of two life traits 
indexes. J Marine Syst. 193: 94-102.

EDWARDS M, RICHARDSON AJ. 2004. Impact of climatic change on marine pelagic phenology and trophic mismatch. Nature. 430: 881-884.

Ferron A, LegGett WC. 1994. An appraisal of condition measures for marine fish larvae. Adv Mar Biol. 30: 217-303.

GovONI JJ. 2005. Fisheries oceanography and the ecology of early life histories of fishes: a perspective over fifty years. Sci Mar. 69: 125137.

HANSEN JE. 2004. Anchoíta (Engraulis anchoita). In: SÁnchez RP, BezzI SI, editors. El Mar Argentino y sus recursos pesqueros. Tomo 4. Los peces marinos de interés pesqueros. Caracterización biológica y evaluación del estado de explotación. Mar del Plata: Instituto Nacional de Investigación y Desarrollo Pesquero (INIDEP). p. 101-115.

HeRnández RD, MEndiolar M. 2018. Programa csmk, implementación de un test no paramétrico para datos estacionales con dependencia serial y datos faltantes. Inf Ases Transf INIDEP No 143/2018: 1-13.

HiRSCH RM, SLACK JR. 1984. A nonparametric trend test for seasonal data with serial dependence. Water Resour. Res. 20: 727-732.

HJORT J. 1914. Fluctuations in the great fisheries of northern Europe viewed in the light of biological research. Rapp P-V Reun Cons int Explor Mer. 20: 1-228.

Leonarduzzi E, Brown DR, SÁnchez R. 2010. Seasonal variations in the growth of anchovy larvae (Engraulis anchoita) on the Argentine coastal shelf. Sci Mar. 74: 267-274.

Lleonart J, Salat J, Torres GJ. 2000. Removing allometric effects of body size in morphological analysis. J Theor Biol. 205: 8593.

Lucas AJ, Guerrero RA, Mianzan HW, Acha EM, LASTA CA. 2005. Coastal oceanographic regimes of the Northern Argentine Continental Shelf $\left(34-43^{\circ}\right.$ S). Estuar Coast Shelf Sci. 65: 405-420.
Mackas DL, Thomson RE, Galbraith M. 2001. Changes in the zooplankton community of the British Columbia continental margin, 19851999, and their covariation with oceanographic conditions. Can J Fish Aquat Sci. 58: 685702.

Madureira LASP, Castello JP, Hernandez CP, QueIroz MI, EsPírito SANTO MLP, RuIz WA, Abdallah PR, Hansen JE, Bertolotti MI, MANCA EA, et al. 2009. Current and potential alternative food uses of the Argentine anchoita (Engraulis anchoita) in Argentina, Uruguay and Brazil. In: HaSAN MR, HALwART M, editors. Fish as feed inputs for aquaculture: practices, sustainability and implications. Rome: FAO. p. 269-287.

Malavolti S, De Felice A, Costantini I, Biagiotti I, Canduci G, Grilli F, Marini M, Tirelli V, Borme D, CAputo Barucchi V, LEONORI I. 2018. Distribution of Engraulis encrasicolus eggs and larvae in relation to coastal oceanographic conditions (a southwestern Adriatic Sea case study). Medit Mar Sci. 19: 180-192.

Martos P, Hansen Je, Negri RM, Madirolas A. 2005. Factores oceanográficos relacionados con la abundancia relativa de anchoíta sobre la plataforma bonaerense $\left(34^{\circ} \mathrm{S}-41^{\circ} \mathrm{S}\right)$ durante la primavera. Rev Invest Desarr Pesq. 17: 5-33.

MatsuURA Y, Kitahara EM. 1995. Horizontal and vertical distribution of anchovy Engraulis anchoita eggs and larvae off Cape Santa Marta Grande in southern Brazil. Arch Fish Mar Res. 42: 239-250.

Matsuura Y, Spach HL, Katsuragawa M. 1992. Comparsion of spawning patterns of the Brazilian sardine (Sardinella brasiliensis) and anchoita (Engraulis anchoita) in Ubatuba region, southern Brazil during 1985 through 1988. Bolm Inst Oceanogr USP. 40: 101-115.

MCGURK MD. 1985. Multivariate analysis of morphometry and dry weight of Pacific herring larvae. Mar Biol. 86: 1-11. 
O’Brien TD, Li WKW, MorÁn XAG. 2012. ICES phytoplankton and microbial plankton status report 2009/2010. ICES Coop Res Rep. 313. $196 \mathrm{p}$.

Pájaro M, Hansen JE, Leonarduzzi E, Garciarena D. 2009. Biomasa de los reproductores de la población boanerense de anchoíta (Engraulis anchoita) en el año 2008: estimación mediante el método de producción diaria de huevos. INIDEP Inf Téc. 29. 19 p.

PÁjaro M, Martos P, LeONARduZzi E, Macchi GJ, DíAz MV, Brown D. 2008. Estrategia de puesta de la anchoita (Engraulis anchoita) en el Mar Argentino y Zona Común de Pesca Argentino-Uruguaya. Inf Téc INIDEP $\mathrm{N}^{\circ}$ 11/2008. 14 p.

Pohlert T. 2018. PMCMRplus. Calculate pairwise multiple comparisons of mean rank sums extended, R package version 1.3.0. https:// cran.r-project.org/web/packages/PMCMR/ PMCMR.pdf.

R CORE TEAm. 2016. R: A language and environment for statistical computing. R Foundation for Statistical Computing, Vienna, Austria. https://www.R-project.org/.

REID JL. 1966. Oceanic environments of the genus Engraulis around the world. Cal Coop Ocean Fish. 11: 29-33.

Richardson AJ, Schoeman DS. 2004. Climate impact on plankton ecosystems in the Northeast Atlantic. Science. 305: 1609-1612.

Rodríguez JM, Alemany F, Garcia A. 2017. A guide to the eggs and larvae of 100 common Western Mediterranean Sea bony fish species. Rome: FAO. 256 p.

SÁNCHEZ RP. 1986. Estudios sobre las variaciones espacio-temporales en los patrones de distribución de embriones y larvas de la anchoíta (Engraulis anchoita), en relación con la estimación de su intensidad reproductiva. Rev Invest Desarr Pesq. 5: 92-142.

SÁNCHEZ RP. 1995. Patrones de distribución espacio-temporal de los estadios embrionarios y larvales de la anchoíta (Engraulis anchoita
Hubbs y Marini) a micro y macroescala, su relación con la supervivencia y el reclutamiento $[\mathrm{PhD}$ thesis]. Buenos Aires: Facultad de Ciencias Exactas y Naturales, Universidad de Buenos Aires. 672 p.

SÁNCHEZ RP, Ciechomski JD. 1995. Spawning and nursery grounds of pelagic fish species in the sea-shelf off Argentina and adjacent areas. Sci Mar. 59: 455-478.

Sato N, Hernández D, Viñas MD. 2011. Hábitos alimentarios de las larvas de Engraulis anchoita (Hubbs \& Marini, 1935) en las aguas costeras de la Provincia de Buenos Aires, Argentina. Lat Am J Aquat Res. 39: 16-24.

Sinclair M, Tremblay MJ. 1984. Timing of spawning of Atlantic herring (Clupea harengus harengus) populations and the match-mismatch theory. Can J Fish Aquat Sci. 41 (7): 1055-1065.

SOMARAKIS S, NikOLIOUdAKIS N. 2007. Oceanographic habitat, growth and mortality of larval anchovy (Engraulis encrasicolus) in the northern Aegean Sea (eastern Mediterranean). Mar Biol. 152: 1143-1158.

Spinelli ML, Guerrero R, PÁjaro M, CAPITANIO FL. 2013. Distribution of Oikopleura dioica (Tunicata, Appendicularia) associated with a coastal frontal system (39 ${ }^{\circ}$ $41^{\circ} \mathrm{S}$ ) of the SW Atlantic Ocean in the spawning area of Engraulis anchoita anchovy. Braz J Oceanogr. 61: 141-148.

Suthers IM. 1998. Biger? Fatter? Or is fast growth better? Considerations on condition in larval and juvenile coral-reef fish. Austral Ecol. 23: 265-273.

Temperoni B, Viñas MD, Diovisalvi N, Negri RM. 2011. Seasonal production of Oithona nana Giesbrecht, 1893 (Copepoda: Cyclopoida) in temperate coastal waters off Argentina. J Plankton Res. 33: 729-740.

THEILACKER G. 1978. Effect of starvation on the histological and morphological characteristics of jack mackerel, Trachurus symmetricus, lar- 
vae. Fish Bull US. 76: 403-414.

Torquato FO, Muelbert JH. 2014. Horizontal and vertical distribution of larvae of Engraulis anchoita (Hubbs \& Marini 1935) off Albardão, Southern Brazil. Pan Am J Aquat Sci. 9: 154-166.

Twatwa NM, van Der Lingen CD, Drapeau L, Moloney CL, Field JG. 2005. Characterising and comparing the spawning habitats of anchovy Engraulis encrasicolus and sardine Sardinops sagax in the southern Benguela upwelling ecosystem. Afr J Mar Sci. 27: 487499.

VIÑAS MD, RAmírez FC. 1996. Gut analysis of first-feeding anchovy larvae from Patagonian spawning area in relation to food availability. Arch Fish Mar Res. 43: 231-256.

Viñas MD, Negri RM, CEPEda GD, HERnÁNDEZ D, Silva RI, Daponte MC, Capitanio FL.
2013. Seasonal succession of zooplankton in coastal waters of the Argentine Sea (Southwest Atlantic Ocean): prevalence of classical or microbial food webs. Mar Biol Res. 9: 371-382.

ViÑAS MD, NegRi, RM, RAMÍREZ FC, HERNÁNDEZ D. 2002. Zooplankton assemblages and hydrography in the spawning area of anchovy (Engraulis anchoita) off Rio de la Plata estuary (Argentina-Uruguay). Mar Freshwater Res. 53: 1031-1043.

Zarrad R, Alemany F, Jarboui O, Garcia A, Akrout F. 2012. Comparative characterization of the spawning environments of European anchovy, Engraulis encrasicolus, and round sardinella, Sardinella aurita (Actinopterygii: Clupeiformes) in the eastern coast of Tunisia. Acta Ichthyol Piscat. 42: 919. 